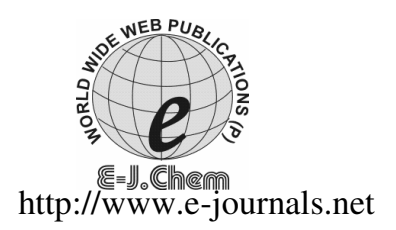

ISSN: 0973-4945; CODEN ECJHAO
E-Journal of Chemistry
2011, 8(4), 1930-1936

\title{
Synthesis and Characterization of Tetrakis(4-oxo-piperidinium ethylene acetal) Bis Sulfate Hexahydrate
}

\author{
H. MAROUANI ${ }^{\S *}$, M. RZAIGUI ${ }^{\S}$ and S. S. AL-DEYAB \\ ${ }^{\S}$ Laboratoire de Chimie des Matériaux \\ Faculté des Sciences de Bizerte, 7021 Zarzouna, Tunisie \\ Petrochemical Research Chair, College of Science \\ King Saud University, Riadh, Saudi Arabia \\ houda.marouani@fsb.rnu.tn
}

Received 27 November 2010; Revised 3 February 2011; Accepted 28 February 2011

\begin{abstract}
Chemical preparation, x-ray characterization, IR spectroscopy and thermal analysis of a new sulfate $\left(\mathrm{C}_{7} \mathrm{H}_{12} \mathrm{O}_{2} \mathrm{NH}_{2}\right)_{4}\left(\mathrm{SO}_{4}\right)_{2} \cdot 6 \mathrm{H}_{2} \mathrm{O}$, are reported. The atomic arrangement can be described by layers formed by sulfate anions $\left(\mathrm{SO}_{4}^{2-}\right)$ and water molecules connected by hydrogen bonds O-H...O. These inorganic layers are developed around ab planes at $\mathrm{z}=0$ and $\mathrm{z}=1 / 2$ and are interconnected by the $H$-bonds created by organic groups. All the hydrogen bonds, the Van der waals contacts and electrostatic interactions between the different entities give rise to a three-dimensional network in the structure and add stability to this compound. The thermal behaviour and the IR spectroscopic studies of this new sulfate are discussed.
\end{abstract}

Keywords: Synthesis, X-ray crystal structure, IR spectroscopy, Thermal behavior

\section{Introduction}

Piperidine is considered as a lysine specific Maillard reaction product that can be formed from free lysine through decarboxylation and deamination reactions ${ }^{1}$. Moreover, some piperidine derivatives are Renin inhibitors with excellent efficacies when administered at low dose to double transgenic rats harboring both the human angiotensinogen and the human Renin gen ${ }^{2}$. Exploration of piperidine as HIV-1 reverse transcriptase inhibitors, with broad potency against resistant mutant viruses ${ }^{3}$. Furthermore, some piperidinium derivatives displayed strong in vitro cytotoxic activity against a panel of cancer cell lines as well as in vitro inhibitory activity against the pathogenic microbes mycobacterium tuberculosis and plasmodium falciparum ${ }^{4}$. 
In order to research new materials of this kind, we report in this work the preparation and the structural investigation of the non-centrosymmetric, $\left(\mathrm{C}_{7} \mathrm{H}_{12} \mathrm{O}_{2} \mathrm{NH}_{2}\right)_{4}\left(\mathrm{SO}_{4}\right)_{2} \cdot 6 \mathrm{H}_{2} \mathrm{O}$. This compound is a new material resulting from the association of organic and inorganic entities and could be an interesting material in the non-linear optics ${ }^{5}$.

\section{Experimental}

Single crystals of the title compound were prepared at room temperature from a mixture of an aqueous solution of sulfuric acid (2 mmol), 1,4-dioxa-8-azaspiro[4.5]decane (4 mmol), ethanol $(10 \mathrm{~mL})$ and water $(10 \mathrm{~mL})$. Schematically, the reaction can be written as follows:

$$
2 \mathrm{H}_{2} \mathrm{SO}_{4}+4\left(\mathrm{C}_{7} \mathrm{H}_{12} \mathrm{O}_{2} \mathrm{NH}\right)+6 \mathrm{H}_{2} \mathrm{O} \longrightarrow\left(\mathrm{C}_{7} \mathrm{H}_{12} \mathrm{O}_{2} \mathrm{NH}_{2}\right)_{4}\left(\mathrm{SO}_{4}\right)_{2} \cdot 6 \mathrm{H}_{2} \mathrm{O}
$$

The resulting solution was evaporated slowly at room temperature for several days until the formation of good prismatic single crystals. The intensity data collection was performed with a CAD4 Enraf Nonius diffractometer. The structure was solved by direct method using the program SHELXS- $97^{6}$ in the WinGX package ${ }^{7}$ and refined by full-matrix least-squares method with the program SHELXL-97 ${ }^{6}$. All non-hydrogen atoms were refined isotropically and then anisotropically by full matrix least-square method. The hydrogen atoms were placed geometrically and treated as riding. The parameters used for the x-ray diffraction data collection as well as the strategy used for the crystal structure determination and its final results are reported in Table 1. The main geometrical features of the hydrogen-bond scheme are provided in Table 2.

The infrared spectrum is recorded in the range 4000-400 $\mathrm{cm}^{-1}$ with a "PerkinElmer FTIR" spectrometer using a sample dispersed in spectroscopically pure $\mathrm{KBr}$ pellet. Thermal analysis was performed using the "Multimodule 92 setaram analyser" operating from room temperature up to $450{ }^{\circ} \mathrm{C}$ at an average heating rate of $5{ }^{\circ} \mathrm{C} \mathrm{min}^{-1}$.

Table 1. Crystal data and experimental parameters used for the intensity measurements

\begin{tabular}{cc}
\hline Empirical formula & $\mathrm{C}_{28} \mathrm{H}_{68} \mathrm{O}_{22} \mathrm{~N}_{4} \mathrm{~S}_{2}$ \\
\hline Formula weight & 876.98 \\
$\mathrm{~T}(\mathrm{~K})$ & 293 \\
Wavelength $(\AA)$ & 0.5608 \\
Crystal system & orthorhombic \\
Space group & Pna2 $2_{1}$ \\
$\mathrm{a}(\AA)$ & $22.1849(10)$ \\
$\mathrm{b}(\AA)$ & $9.928(2)$ \\
$\mathrm{c}(\AA)$ & $19.160(3)$ \\
$\mathrm{Z}$ & 4 \\
$\mathrm{~V}\left(\AA^{3}\right)$ & $4220.1(11)$ \\
$\rho_{\text {cal. }}, \mathrm{g} \mathrm{cm}{ }^{-3}$ & 1.380 \\
$\mathrm{~F}(000)$ & 1888 \\
$\mu(\mathrm{AgK} \alpha)$ & $0.12 \mathrm{~mm}$ \\
$\mathrm{Crystal}$ size $[\mathrm{mm}]$ & $0.35 \times 0.25 \times 0.20$ \\
$9478\left(\mathrm{R}_{\text {int. }}=0.0000\right)$ & $9478\left(\mathrm{R}_{\text {int. }}=0.0000\right)$ \\
$\mathrm{R}\left[\mathrm{F}^{2>} 2 \sigma\left(\mathrm{F}^{2}\right)\right]$ & 3272 \\
$w \mathrm{R}\left(\mathrm{F}^{2}\right)$ & 0.063 \\
$\Delta \rho_{\min }, \Delta \rho_{\max }$ & 0.181 \\
Goodness-of-fit & $-0.30,0.30 \mathrm{e} \AA^{3}$ \\
Unique reflections $i n c l u d:$ & 0.92 \\
\hline
\end{tabular}


Table 2. Hydrogen-bond geometry $\left(\AA,^{\circ}\right)$ in $\left(\mathrm{C}_{7} \mathrm{H}_{12} \mathrm{O}_{2} \mathrm{NH}_{2}\right)_{4}\left(\mathrm{SO}_{4}\right)_{2} \cdot 6 \mathrm{H}_{2} \mathrm{O}$

\begin{tabular}{|c|c|c|c|c|}
\hline D-H...A & $\mathrm{D}-\mathrm{H}(\AA)$ & H...А $(\AA)$ & D...A $(\AA)$ & D-H...A $\left(^{\circ}\right)$ \\
\hline N1-H1A...O4A & 0.90 & 1.77 & $2.650(14)$ & 165.8 \\
\hline N1-H1A...O4B & 0.90 & 1.88 & $2.731(15)$ & 157.0 \\
\hline N1-H1B...O6 & 0.90 & 2.16 & $3.015(10)$ & 157.7 \\
\hline N1-H1B... O8 & 0.90 & 2.29 & $3.038(15)$ & 140.2 \\
\hline N2-H2A ...O6 & 0.90 & 1.88 & $2.774(9)$ & 174.5 \\
\hline $\mathrm{N} 2-\mathrm{H} 2 \mathrm{~B} \ldots \mathrm{O} 1^{\mathrm{i}}$ & 0.90 & 1.83 & $2.718(10)$ & 167.6 \\
\hline N3-H3A...O7B ${ }^{\text {ii }}$ & 0.90 & 1.79 & $2.694(15)$ & 176.3 \\
\hline N3-H3A...O7A ${ }^{\mathrm{ii}}$ & 0.90 & 1.96 & $2.831(14)$ & 163.1 \\
\hline $\mathrm{N} 3-\mathrm{H} 3 \mathrm{~B} \ldots \mathrm{O} 1^{\mathrm{iii}}$ & 0.90 & 1.91 & $2.786(10)$ & 163.4 \\
\hline $\mathrm{N} 4-\mathrm{H} 4 \mathrm{C} \ldots \mathrm{O} 7 \mathrm{~A}^{\mathrm{iii}}$ & 0.90 & 2.09 & $2.936(14)$ & 156.3 \\
\hline N4-H4C ...O7B & 0.90 & 2.30 & $3.131(16)$ & 153.9 \\
\hline $\mathrm{N} 4-\mathrm{H} 4 \mathrm{C} \ldots \mathrm{O} 8^{\mathrm{iii}}$ & 0.90 & 2.51 & $3.252(16)$ & 140.7 \\
\hline N4-H4D...O2B ${ }^{\mathrm{iii}}$ & 0.90 & 1.80 & $2.674(15)$ & 162.6 \\
\hline N4-H4D...O2A $\mathrm{A}^{\mathrm{iii}}$ & 0.90 & 1.84 & $2.716(18)$ & 163.5 \\
\hline O17-H117...O19 & $0.851(10)$ & $2.08(3)$ & $2.812(8)$ & $144(4)$ \\
\hline $\mathrm{O} 17-\mathrm{H} 217 \ldots \mathrm{O} 21^{\text {iv }}$ & $0.851(10)$ & $1.93(4)$ & $2.734(6)$ & $158(9)$ \\
\hline O18-H118...O17 & $0.851(11)$ & $1.975(12)$ & $2.826(5)$ & $178(5)$ \\
\hline O18-H218...O4A & $0.846(10)$ & $2.04(3)$ & $2.836(19)$ & $157(5)$ \\
\hline O18-H218...O2B & $0.846(10)$ & $2.28(5)$ & $2.745(17)$ & $115(4)$ \\
\hline $\mathrm{O} 19-\mathrm{H} 119 \ldots \mathrm{O} 20^{\mathrm{i}}$ & $0.851(10)$ & $1.96(4)$ & $2,766(7)$ & $158(8)$ \\
\hline O19-H219...O6 & $0.845(10)$ & $2.51(4)$ & $3.126(13)$ & $131(5)$ \\
\hline $\mathrm{O} 20-\mathrm{H} 120 \ldots \mathrm{O} 22^{\mathrm{v}}$ & $0.846(10)$ & $2.03(2)$ & $2.796(5)$ & $150(4)$ \\
\hline $\mathrm{O} 20-\mathrm{H} 220 \ldots \mathrm{O} 3 \mathrm{~A}$ & $0.850(10)$ & $2.33(5)$ & $3.053(17)$ & $144(6)$ \\
\hline $\mathrm{O} 20-\mathrm{H} 220 \ldots \mathrm{O} 3 \mathrm{~B}$ & $0.850(10)$ & $2.38(2)$ & $3.22(2)$ & $169(4)$ \\
\hline O20- H220...O1 & $0.850(10)$ & $2.57(4)$ & $3.168(5)$ & $128(4)$ \\
\hline $\mathrm{O} 21-\mathrm{H} 121 \ldots \mathrm{O} 3 \mathrm{~A}$ & $0.851(10)$ & $2.19(3)$ & $2.944(18)$ & $148(4)$ \\
\hline O20- H220...O3B & $0.850(10)$ & $2.38(2)$ & $3.22(2)$ & $118(3)$ \\
\hline $\mathrm{O} 21-\mathrm{H} 221 \ldots \mathrm{O} 8$ & $0.851(10)$ & $1.84(3)$ & $2.655(6)$ & $161(6)$ \\
\hline O22-H122...O5 & $0.850(10)$ & $2.12(4)$ & $2.870(4)$ & $147(7)$ \\
\hline $\mathrm{O} 22-\mathrm{H} 222 \ldots \mathrm{O} 18^{\mathrm{i}}$ & $0.850(10)$ & $1.98(2)$ & $2.774(6)$ & $156(5)$ \\
\hline C5-H5B...O12 $2^{\mathrm{vi}}$ & 0.97 & 2.53 & $3.463(12)$ & 161.6 \\
\hline C11-H11A...O4B ${ }^{\mathrm{i}}$ & 0.97 & 2.28 & $3.182(17)$ & 155.0 \\
\hline C12-H12B...O10 & 0.97 & 2.55 & $3.503(12)$ & 168.0 \\
\hline C15-H15B...O15 & 0.97 & 2.49 & $3.455(13)$ & 172.1 \\
\hline C16-H16А...O2A & 0.97 & 2.35 & 3.255(19) & 155.7 \\
\hline C23-H23A...O7A & 0.97 & 2.53 & $3.277(16)$ & 133.5 \\
\hline $\mathrm{C} 25-\mathrm{H} 25 \mathrm{~B} \ldots \mathrm{O} 7 \mathrm{~B}^{\mathrm{iii}}$ & 0.97 & 2.53 & $3.322(17)$ & 138.9 \\
\hline
\end{tabular}

Symmetry codes: (i) $x+1 / 2,-y+1 / 2, z$; (ii) $-x+2,-y+1, z+1 / 2$; (iii) $-x+3 / 2, y+1 / 2, z+1 / 2$; (iv) $x, y+1, z$; (v) $x-1 / 2,-y-1 / 2, z$; (vi) $x-1 / 2,-y+1 / 2, z$; (vii) $x+1 / 2,-y+3 / 2, z$

\section{Results and Discussion}

\section{Crystal description}

Asymmetric unit of the title compound is built up from two sulfate anions, four organic cations and six water molecules. Its geometrical configuration is depicted in the Figure 1. The atomic arrangement of the title compound is characterized by the existence of inorganic layers, generated by the periodic motif $\left[\mathrm{S}_{2} \mathrm{O}_{8}\left(\mathrm{H}_{2} \mathrm{O}\right)_{6}\right]^{4-}$. These layers cross the unit cell parallel 
to the (a, b) plane at $\mathrm{z}=0$ and $\mathrm{z}=1 / 2$ (Figure 2). Between these layers, separated by a distance of $9.580 \AA$, organic cations establish hydrogen bonds to interconnect the different anions. The $\mathrm{SO}_{4}^{2-}$ ions are bonded to the water molecules through single, bifurcated and trifurcated $\mathrm{O}-\mathrm{H}$... O hydrogen bonds.

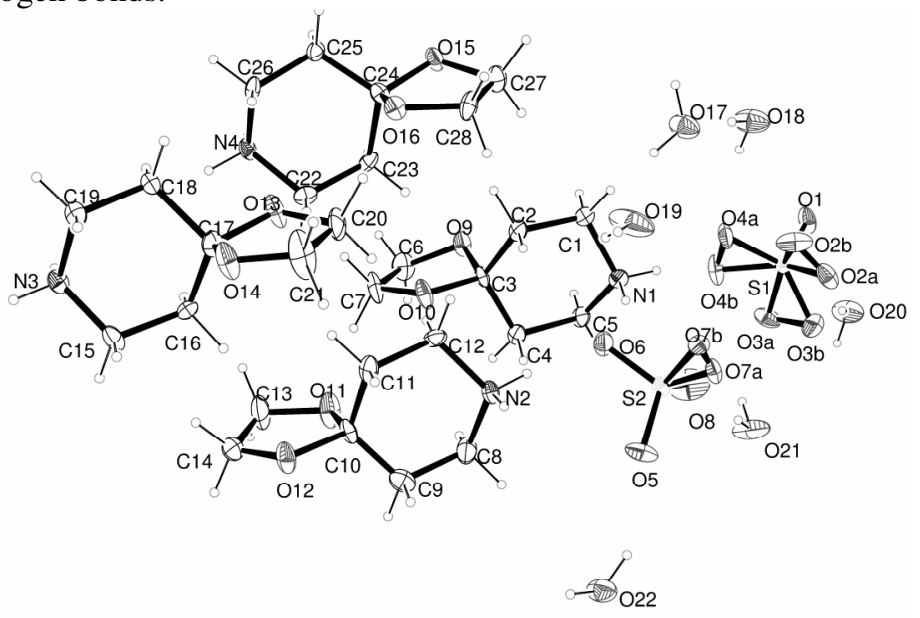

Figure 1. ORTEP Drawing showing the asymmetric unit of $\left(\mathrm{C}_{7} \mathrm{H}_{12} \mathrm{O}_{2} \mathrm{NH}_{2}\right)_{4}\left(\mathrm{SO}_{4}\right)_{2} \cdot 6 \mathrm{H}_{2} \mathrm{O}$ with the atom-labelling scheme. Displacement ellipsoids are drawn at the $30 \%$ probability level. $\mathrm{H}$ atoms are represented by spheres of arbitrary radii



Figure 2. Projection of $\left(\mathrm{C}_{7} \mathrm{H}_{12} \mathrm{O}_{2} \mathrm{NH}_{2}\right)_{4}\left(\mathrm{SO}_{4}\right)_{2} \cdot 6 \mathrm{H}_{2} \mathrm{O}$ structure along the $b$ axis

The title compound contains distorted tetrahedral $\mathrm{SO}_{4}^{2-}$ anions, so four oxygen atoms $(\mathrm{O} 2, \mathrm{O} 3, \mathrm{O} 4$ and $\mathrm{O} 7)$ are distorted over two sets in 0.5:0.5 ratio. The sulfate ion $\mathrm{S}_{1} \mathrm{O}_{4}^{2-}$ is disordered over two sites related by rotation around the S1-O1 bond in an "umbrella" type of disorder (only three of four oxygen atoms are disordered), a similar case has been observed in the structure of tris(diisopropylammonium) hydrogensulfate sulfate ${ }^{8}$. In the other sulfate ion $\mathrm{S}_{2} \mathrm{O}_{4}^{2-}$, the oxygen atom $\mathrm{O} 7$ is disordered over two positions $(\mathrm{O} 7 \mathrm{~A}$ and $\mathrm{O} 7 \mathrm{~B})$ with equal occupancy. We can notice that the presence of the disordered tetrahedral encourages the formation of bifurcated and trifurcated hydrogen bonds. 
Four independent 4-oxo-piperidinium ethylene acetal cations are identified in crystal structure. Interatomic bond lengths and angles in these entities spread within the ranges [1.325(12)-1.573(13) $\AA$ ] and [102.2(8)-113.8(8) ${ }^{\circ}$, respectively. These values are similar to those obtained for the same organic group in other compound ${ }^{9}$. The organic cations are localized in the interlayer spacing and arranged in the same direction. The organic molecule contains two rings joined at the carbon atom. The first ring presents a planar part that contains two oxygen atoms with a mean plane deviation of $0.045 \AA$, while the second one exhibits a chair conformation.

All the amino hydrogen atoms are involved in N-H...O hydrogen bonding, as well as weak $\mathrm{C}-\mathrm{H} . . . \mathrm{O}$ interactions. In the $\mathrm{N}-\mathrm{H}$... O bonds, the $\mathrm{H}$... O bond lengths are in the range $1.77-2.51 \AA$ and the H...O distances in the C-H...O bonds are in the $2.28-2.55 \AA$ range (Table 2). The adjacent layers interact via $\mathrm{N}-\mathrm{H} . . . \mathrm{O}$ and $\mathrm{C}-\mathrm{H} . . . \mathrm{O}$ hydrogen bonding along the $\mathrm{b}$-axis to form 3D network.

There are six crystallographically independent water molecules $\mathrm{O}(17), \mathrm{O}(18), \mathrm{O}(19)$, $\mathrm{O}(20), \mathrm{O}(21)$ and $\mathrm{O}(22)$ in this atomic arrangement. They interconnect the sulfate anions and the organic groups via hydrogen bonds. The cohesion forces in this compound are assured by electrostatic interactions, van der Waals contacts and hydrogen bonds $(\mathrm{O}-\mathrm{H} \cdots \mathrm{O}$, $\mathrm{N}-\mathrm{H} \cdots \mathrm{O}$ and $\mathrm{C}-\mathrm{H} . . . \mathrm{O})$.

\section{Thermal BEhavior}

Figure 3 shows both TG and DTA thermograms of the hybrid compound heated from room temperature to $450{ }^{\circ} \mathrm{C}$ at $5{ }^{\circ} \mathrm{C} \mathrm{min}^{-1}$. From these curves, we deduce that the thermal decomposition occurs in two stages. The first one corresponds to the removal of the six water molecules (weight loss calculated $12.31 \%$, observed $12.19 \%$ ) in the temperature range 50-115 ${ }^{\circ} \mathrm{C}$. This is related to the endothermic peak on the DTA curve at $91{ }^{\circ} \mathrm{C}$. The force of the hydrogen bonds in the network explains the removal of the water molecules in this large temperature range. The endothermic peak at $149^{\circ} \mathrm{C}$ is assigned to a phase transition. In order to detect the phase transition and to examine the nature of this transformation, DSC measurements have been undertaken. A result of calorimetric study is represented in Figure 4, which represents the diagram obtained during heating and cooling scans a recently prepared crystals of $\left(\mathrm{C}_{7} \mathrm{H}_{12} \mathrm{O}_{2} \mathrm{NH}_{2}\right)_{4}\left(\mathrm{SO}_{4}\right)_{2} \cdot 6 \mathrm{H}_{2} \mathrm{O}$. The diagram shows the appearance of the peak of the phase transition only in the heating cycle at $155^{\circ} \mathrm{C}$. That proves that the phase transition is irreversible.

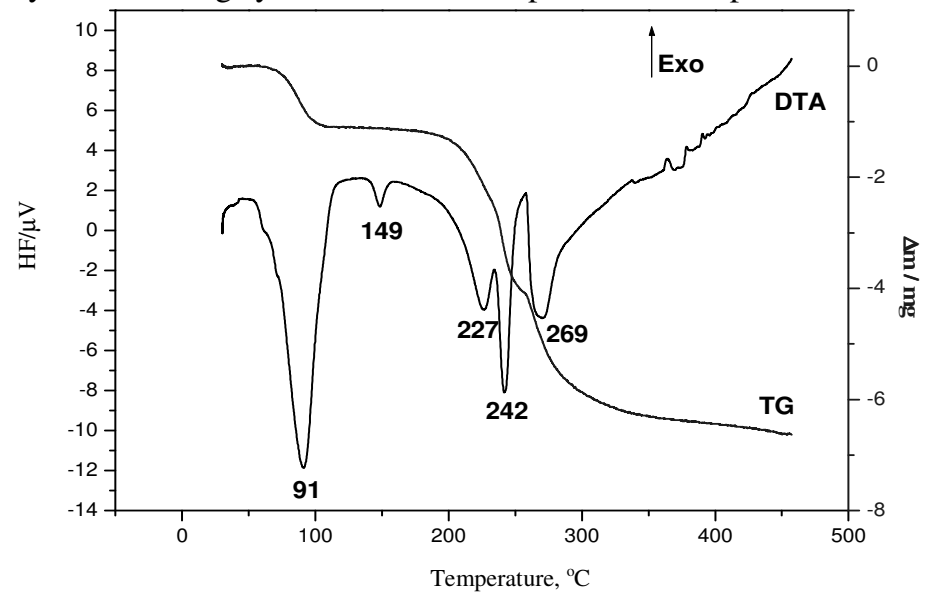

Figure 3. DTA and TG curves of $\left(\mathrm{C}_{7} \mathrm{H}_{12} \mathrm{O}_{2} \mathrm{NH}_{2}\right)_{4}\left(\mathrm{SO}_{4}\right)_{2} \cdot 6 \mathrm{H}_{2} \mathrm{O}$ 


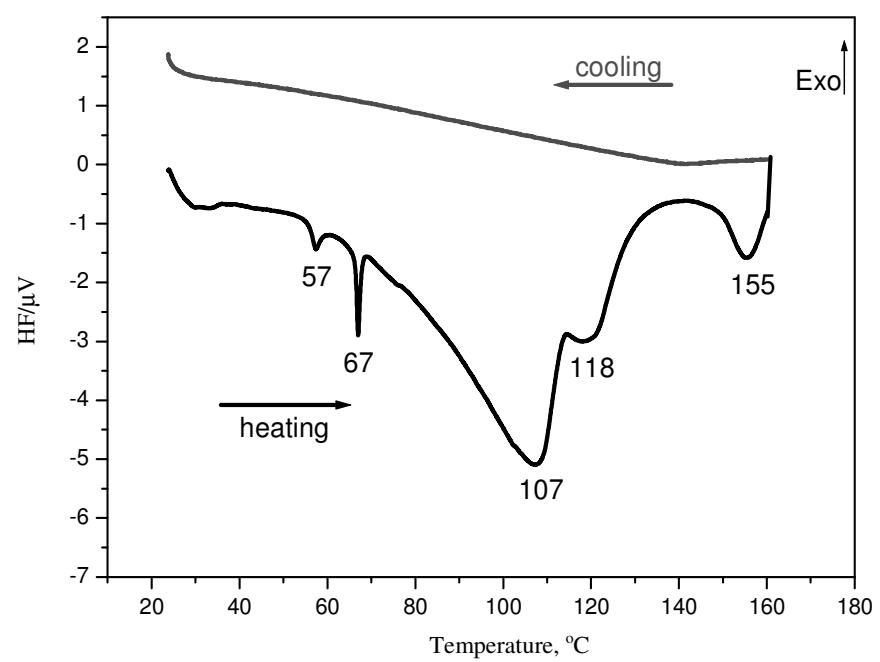

Figure 4. DSC curves obtained upon heating and cooling of $\left(\mathrm{C}_{7} \mathrm{H}_{12} \mathrm{O}_{2} \mathrm{NH}_{2}\right)_{4}\left(\mathrm{SO}_{4}\right)_{2} \cdot 6 \mathrm{H}_{2} \mathrm{O}$

The second process related to the others endothermic peak observed in the DTA at 227, 242 and $269{ }^{\circ} \mathrm{C}$ correspond to a degradation of the obtained phase in a wide temperature range $\left[200-300{ }^{\circ} \mathrm{C}\right]$.

\section{IR spectroscopy}

The infrared absorption spectrum of the title compound reported in Figure 5 shows vibrations band characteristic of the organic cation, the $\mathrm{SO}_{4}^{2--}$ anion and the water molecule. The assignment attempts are based on previous results encountered in the literature ${ }^{10,11}$ and on the predictions of group theoretical analysis. Multiple bands extending from 3400 to $2500 \mathrm{~cm}^{-1}$ are observed in the IR spectrum. These bands are due to the symmetric and asymmetric stretching modes of $\mathrm{H}_{2} \mathrm{O}, \mathrm{NH}_{2}, \mathrm{CH}_{2}$ and $\mathrm{OH}^{9}$. Frequencies in the range 1700-1300 are attributed to $\delta\left(\mathrm{H}_{2} \mathrm{O}\right), \delta\left(\mathrm{NH}_{2}\right), \delta\left(\mathrm{CH}_{2}\right)$ and $\delta(\mathrm{OH})^{9}$ bending vibrations.

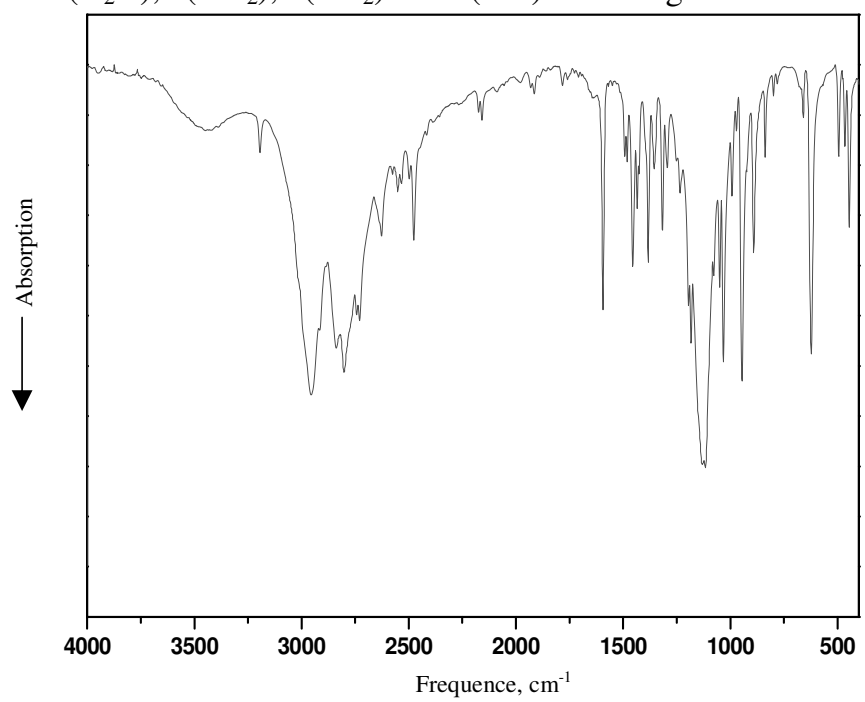

Figure 5. Infrared absorption spectrum of $\left(\mathrm{C}_{7} \mathrm{H}_{12} \mathrm{O}_{2} \mathrm{NH}_{2}\right)_{4}\left(\mathrm{SO}_{4}\right)_{2} \cdot 6 \mathrm{H}_{2} \mathrm{O}$ 
Various valency and bending vibration bands, whose number and positions are between 1200 and $300 \mathrm{~cm}^{-1}$, are both characteristic of a sulfate anion. The isolated $\mathrm{SO}_{4}{ }^{2-}$ tetrahedron with an ideal $\mathrm{T}_{\mathrm{d}}$ symmetry has four vibrational modes: the non-degenerate symmetric stretching mode $v_{1}\left(\mathrm{~A}_{1}\right)$; the doubly degenerate bending mode $v_{2}(\mathrm{E})$; the triply asymmetric stretching mode $v_{3}\left(\mathrm{~F}_{2}\right)$ and the triply degenerate asymmetric bending mode $v_{4}\left(\mathrm{~F}_{2}\right)$. All the modes are Raman active, whereas only $v_{3}$ and $v_{4}$ are active in the IR. These modes are observed at $981,451,1104$, and $614 \mathrm{~cm}^{-1}$, respectively ${ }^{12}$. In the crystal, the $\mathrm{SO}_{4}^{2-}$ anion occupies lower site symmetry $\mathrm{C}_{1}$, a result the IR inactive modes $v_{1}$ and $v_{2}$ may become active and the degeneracy of $v_{2}, v_{3}$ and $v_{4}$ modes may be removed. The degenerate $v_{2}$ mode of the ion is found to be split into two components around 441 and $451 \mathrm{~cm}^{-1}$. Appearance of this IR inactive mode can be due the symmetry lowering of the $\mathrm{SO}_{4}{ }^{2-}$ ion from $\mathrm{T}_{\mathrm{d}}$ to $\mathrm{C}_{1}$. The $v_{3}$ mode appears as three bands at 1018 , 1047 and $1125 \mathrm{~cm}^{-1}$. The $v_{4}$ mode is also observed as three bands at 492, 590 and $620 \mathrm{~cm}^{-1}$. The non-degenerate stretching mode $v_{1}$ appears as one band at $944 \mathrm{~cm}^{-1}$.

\section{Supplementary material}

Crystallographic data (CIF) for the structure reported in this paper have been deposited in the Cambridge crystallographic data centre as supplementary materials No CCDC 802225. Copies of the data can be obtained, free of charge, on application to the CCDC, 12 Union Road, Cambridge CB12EZ, UK

\section{Conclusion}

The use of the protonated 4-oxo-piperidinium ethylene acetal as organic cation in the sulfate matrix leads to a new hybrid compound of the chemical formula $\left(\mathrm{C}_{7} \mathrm{H}_{12} \mathrm{O}_{2} \mathrm{NH}_{2}\right)_{4}\left(\mathrm{SO}_{4}\right)_{2} \cdot 6 \mathrm{H}_{2} \mathrm{O}$. Crystal structure of this compound was found to be built by infinite layers of $\mathrm{SO}_{4}^{2-}$ and water molecules parallel to the ab planes around $\mathrm{z}=0$ and $\mathrm{z}=1 / 2$. Between these layers the organic cations are located. Both inorganic and organic components perform different interactions (electrostatic, $H$-bonds and van der waals) to stabilize the three-dimensional network. When heated, the compound loses the crystallization water molecules at $91{ }^{\circ} \mathrm{C}$. By heating further, the compound exhibits a degradation of the organic entities confirmed by the obtained carbon black residue at the end of the experiment.

\section{References}

1. Nikolov P Y and Yaylayan V A, Food Chem., 2010, 123, 684-690.

2. Corminboeuf O, Bezençon O, Remeň Ĺ, Crisostomi C, Richard- Bildstein S, Bur D, Prade L, Strickner P, Hess P, Fischli W, Steiner B and Treiber A, Bioorg Med Chem Lett., 2010, 20(21), 6291-6296.

3. Tang G, Kertesz D J, Yang M, Lin X, Wang Z, Li W, Qiu Z, Chen J, Mei J, Chen L, Mirzadegan T, Harris S F, Villaseñor A G, Fretland J, Fitch W L, Hang J Q, Heilek G and Klumpp K, Bioorg Med Chem Lett., 2010, 20, 6020.

4. Wei X, Nieves K and Rodríguez A D, Bioorg Med Chem Lett., 2010, 20(19), 5905-5908.

5. Masse R, Bagieu-Beucher M, Pecaut J, Levy J P and Zyss M, J Nonlinear Opt., 1993, 5, 413.

6. Sheldrick G M, Acta Cryst., 2008, A64, 112-122.

7. Farrugia L J, J Appl Cryst., 1999, 32, 837-838.

8. Mohammadnezhad G S, Amini M M, Khavasi H R and Ng S W, Acta Cryst., 2008, E64, o1564.

9. Dhaouadi H, Marouani H, Rzaigui M, Al-Deyab S S and Madani A, Phosphorus Sulfur Silicon, 2010, 185(3), 609-619.

10. Guerfel T and Jouini A, Mater Res Bull., 2007, 42, 149.

11. Cihelka J, Havlícek D, Gyepes R, Nemec I and Koleva Z, J Mol Struct., 2010, 980, 31-38.

12. Hertzberg G, Infrared and Raman Spectra of Polyatomic Molecules, Van Nostrand, New York, 1966. 


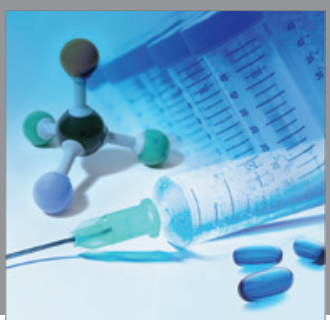

International Journal of

Medicinal Chemistry

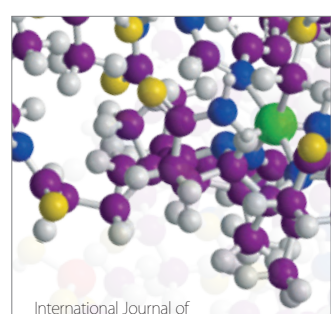

Carbohydrate Chemistry

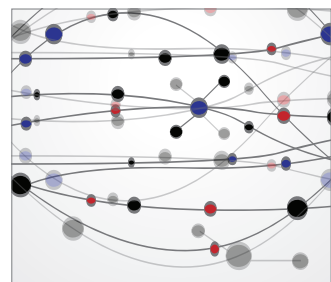

The Scientific World Journal
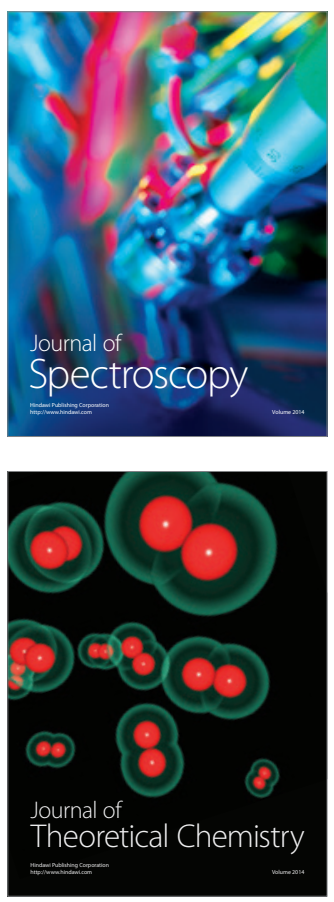
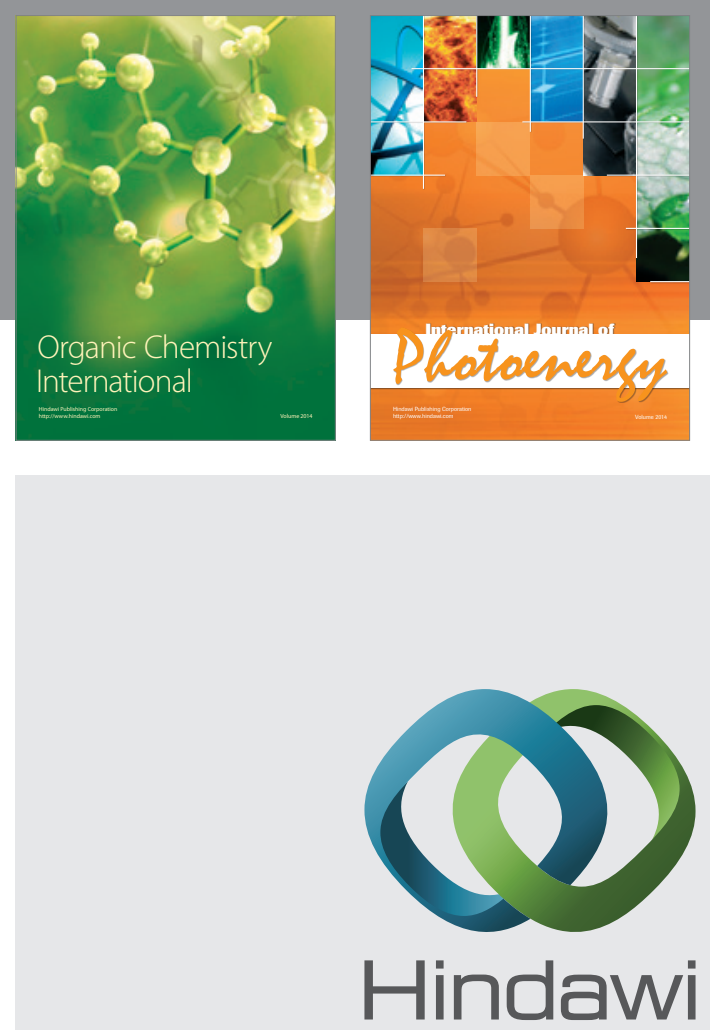

Submit your manuscripts at

http://www.hindawi.com
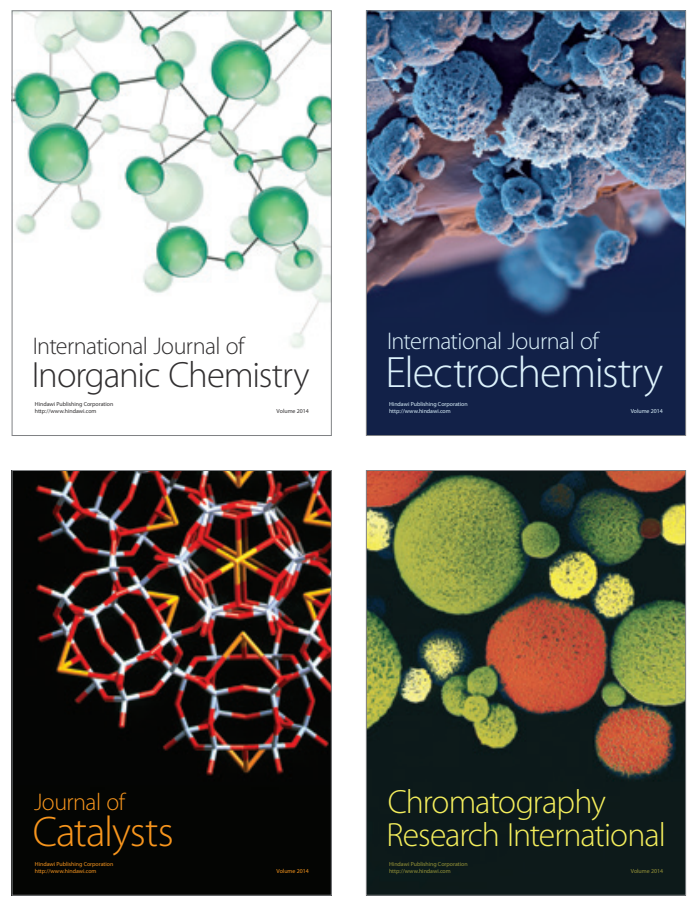
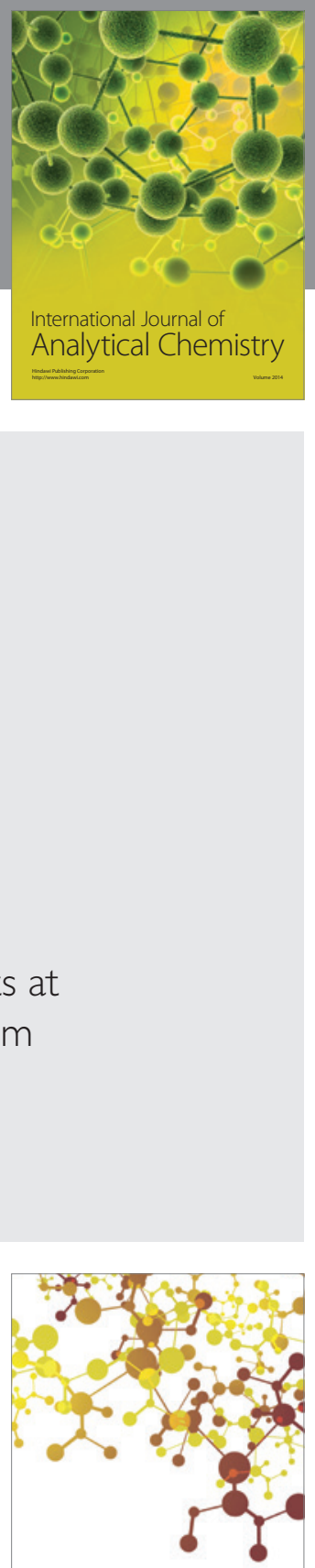

Journal of

Applied Chemistry
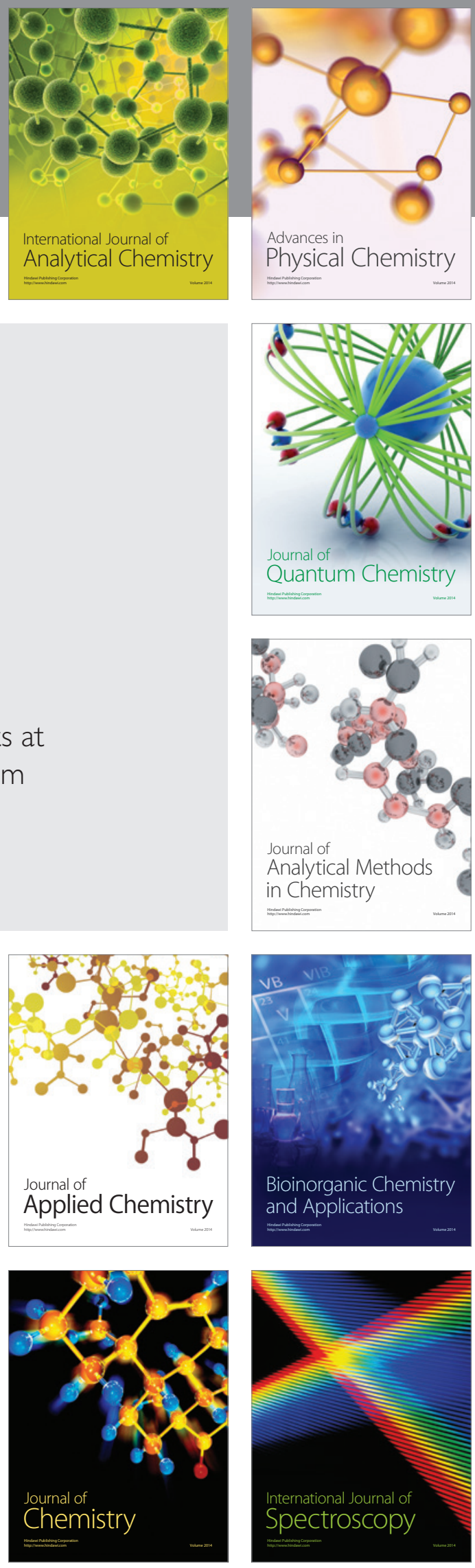